\title{
UTILIZING ASSOCIATED GAS TO GENERATE ELECTRICAL POWER TO REPLACE THE TRADITIONAL CRUDE / DIESEL FUEL AS SOURCE OF ENERGY FOR OIL \& GAS FIELDS
}

\author{
Elmamoun Ibrahim Mustafa \\ PHD Studtudant \\ Faculty of Engineering \& Technology, Nile Valley \\ University, Atbara, River Nile, Sudan.
}

\begin{abstract}
In the production of oil and gas wells, hot water, sand and gas is produced along with the hydrocarbon product. Several of these wells/fields produce associated natural can be used to generate power for site consumption. To verify this concept, 2B OPCO oil and gas national company (Formerly GNPOC) in Sudan, at block 4 oil field through Development Department started initiative to enter into a Cooperative Research and Development to demonstrate small scale power generation from utilizing associated gas.
\end{abstract}

This Paper deals with the utilization of associated gas to electrical power. considers amount of associated gas daily being Flared in the atmosphere, It deals with number of fact that although there are essential need of using of traditional fossil fuel as energy source for industrial plants, there are several related concerns associated with the utilizing it in producing energy, utilization the fossil fuel (diesel ,crude oil ...etc.) specially in electrical power to cover industrial plant electrical power demands (commercial plants ,factories ,residential, oil \& gas fields....etc.) for production and processing of products or supplying services as well as auxiliary power for utilities, fuel cost and fuel logistics results in concerns for using the traditional fossil fuel like diesel and crude oil as energy source ,other issues of environmental impact e.g. air pollution, acidification and material waste.

This paper took a hybrid approach, Study the requirements of Utilizing associated gas in electrical power generation, select the suitable solution for power generation from associated gas and collect the all data required for analysis.

Keywords: Associated gas, gas to power, gas utilization, natural gas, power generation.

\section{INTRODUCTION}

The block 4 oil and gas in located at South Kordofan state, Crude oil and natural gas in block 4 Sudan is produced in the Muglad basins, there are three fields NEEM, DIFFRA and CANAR, mainly the natural gas produced in NEEM field.

The usage of traditional energy sources to produce electrical power is very important when considering the sustainability
Hassan Khlifa, Mohamed Ibrahim Shukr

Department of Mechanical Engineering

Faculty of Engineering \& Technology, Nile Valley

University, Atbara, river Nile, Sudan.

of the existing energy usage of the world. While there is currently an abundance of non-renewable energy sources, such as diesel, crude oil, cool...etc. fuels. So it is important to use other Potential energy resources of cost effective, easy and sustainable sources of fuel for power generation from the viewpoint of different promising available technologies and energy resources. [1]

Electrical power is now the backbone of modern industrial society and it is the heart of many modern technologies, being used for oil and gas fields as prime mover of oil and gas facilities equipment for industrial development and activities. So the electrical energy continuity means directly production continuity; power system always designed with a minimum disturbance and has features to give the maximum dependability consistent with the plant requirements and justifiable cost. [2]

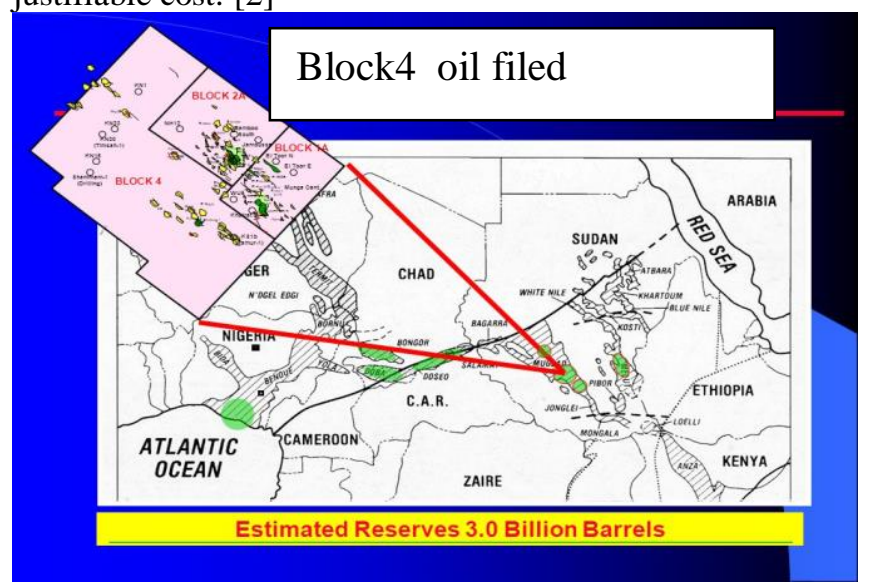

Figure (1) Block4 oil filed

\section{FUEL CONSUMPTION IN POWER GENERATION}

The electrical energy generated in oil and gas fields industry is the totality of all of the electrical consumption of equipment's involved in the oil and gas production, so to production the electrical power to supply all electrical equipment's which consumes large amounts of energy and consequently large amount of fuel for electricity generation. Diesel oil, crude oil, and heavy fuel oil are used for electricity generation in oil field especially crude for producing electricity in power plants. [3] 
Operation expenditure (OPEX) now has become a nightmare in oil and gas industry, because of high fuel consumption cost in additional to oil price fluctuation for last few years all this and also the cost of maintenance and spare parts cost due to aging of power plants equipment. [4]

Average of 50,000 $\mathbf{b b l}$. Of crude oil fuel consumption per year at NEEM field and Average of 25,000 bbl. of diesel per year at DIFFRA and CANAR fields see table (1) daily and yearly fuel consumption

On the other hand, Average of 7.1 Billion SCF (Standard cubic feet) Per year of associated Gas being Flared which considered as losses energy and all most free fuel.[4]

Table (1) show the total Fuel consumption of the existing power generation plants and fuel type as following:

Table (1) daily and yearly and type of fuel consumption

\begin{tabular}{|l|c|c|c|}
\hline $\begin{array}{c}\text { Power } \\
\text { Plant }\end{array}$ & $\begin{array}{c}\text { Fuel } \\
\text { type }\end{array}$ & $\begin{array}{c}\text { Fuel } \\
\text { consumption } \\
\text { (daily) }\end{array}$ & $\begin{array}{c}\text { Fuel consumption } \\
\text { (yearly) }\end{array}$ \\
\hline $\begin{array}{l}\text { Neem } \\
\text { power } \\
\text { plant }\end{array}$ & Crude & $135 \mathrm{bbl}$ /Day & $(50,000 \mathrm{bbl}$.) \\
\hline $\begin{array}{l}\text { Diffra } \\
\text { power } \\
\text { plant }\end{array}$ & Diesel & $55 \mathrm{bbl}$. /Day & $(20,000 \mathrm{bbl})$. \\
\hline $\begin{array}{l}\text { Canar } \\
\text { power } \\
\text { plant }\end{array}$ & Diesel & $13 \mathrm{bbl}$. /Day & $(5,000 \mathrm{bbl})$. \\
\hline
\end{tabular}

Many efforts have been exerted in the area of fuel consumption and utilizing of Available associated gas in power generation can be a cost effective approach.

Because of this high Fuel cost plus Maintenance cost and the need of the company for cost optimization by using associated gas to generate the power will be cost effective approach to reduce the overall operation expenditure (OPEX). In same time to maintain power demands to cover future demand and needs without affecting the power system stability and reliability.

To solve fuel consumption problem by utilizing associated gas at Block 4 fields (NEEM, DIFFRA and CANAR) instead of burning diesel fuel and crude oil fuel ,the few points below to support the proposed solution:-

- Study the gas availability and sustainability in the different block 4 fields.

- Study the load profile to provide enough Gas engine Units work on associated gas to generate the required power demand by all fields.

- Study the Construction of Transmission Line to connect all three field to gather in case of un availability of gas in each field

- Study the existing power system and effect of the new proposed solution on the stability operability ....act.

- Study the other requirement to support the new system.
2B OPCO operating company Ltd Formerly (GNPOC) operates and maintains its own power systems to supply the production facilities within isolated networks, of which the main network supplies all fields in Block 1 and 2. Remote fields like Neem in Block 4 are supplied from their own isolated power systems.

The power generation within these networks is based on diesel generating sets fueled by local Crude oil as main fuel and LFO (Diesel oil) supplied by truck as backup or temporary fuel

66 and $33 \mathrm{kV}$ feeders supplying various Field Processing facilities (FPF) / Oil Gathering Stations through a transmission line and cable network of approx. $195 \mathrm{~km}$ length. The $33 \mathrm{kV}$ Field Surface Facilities (FSF) distribution overhead lines feeding various well sites (total length approx.175 km) $33 \mathrm{kV}$ underground cables feeding various well sites.

Details of the existing power system installed and firm power value of electrical power generation from crude /diesel fuel as following for the three fields power plants at block 4. [5]

Table (2) shows the existing power system generation in block (4):-

\begin{tabular}{|c|c|c|c|c|c|c|}
\hline \multirow[b]{2}{*}{$\begin{array}{l}\text { power } \\
\text { Plants }\end{array}$} & \multicolumn{2}{|c|}{ Permanent (MW) } & \multicolumn{2}{|c|}{$\begin{array}{l}\text { Portable } \\
\text { (MW) }\end{array}$} & \multirow[b]{2}{*}{$\begin{array}{c}\text { Total } \\
\text { Firm } \\
\text { Capa } \\
\text { city } \\
\text { (MW } \\
\text { ) }\end{array}$} & \multirow[b]{2}{*}{$\begin{array}{c}\text { MA } \\
\text { Dem } \\
\text { and } \\
\text { (MW } \\
\text { ) }\end{array}$} \\
\hline & $\begin{array}{l}\text { Installed } \\
\text { Capacity }\end{array}$ & $\begin{array}{c}\text { Firm } \\
\text { Capaci } \\
\text { ty } \\
(\mathrm{N}-2 * \\
\mathbf{0 . 8})\end{array}$ & $\begin{array}{c}\text { Inst } \\
\text { alle } \\
\text { d } \\
\text { Cap } \\
\text { acit } \\
\text { y }\end{array}$ & $\begin{array}{c}\text { Firm } \\
\text { Capa } \\
\text { city } \\
(\mathrm{N}- \\
(20 r 3 \\
)^{*} \\
0.8)\end{array}$ & & \\
\hline $\begin{array}{c}\text { NEE } \\
\mathbf{M}\end{array}$ & $\begin{array}{l}5 \text { Crude } \\
\text { Engine } \\
(5 \times 1.6) \\
=8\end{array}$ & $\begin{array}{c}4 \\
\text { Crude } \\
\text { Engine } \\
\mathbf{5 . 1 2}\end{array}$ & ----- & ---- & 5.12 & 4.4 \\
\hline $\begin{array}{c}\text { DIFF } \\
\text { RA }\end{array}$ & - & - & $\begin{array}{l}7.5 \\
(5 \times 1 \\
.6)\end{array}$ & 2.56 & 2.56 & 2.1 \\
\hline $\begin{array}{c}\text { CAN } \\
\text { AR }\end{array}$ & - & - & $\begin{array}{c}2.5 \\
(5 \times 0 \\
.5)\end{array}$ & 1.2 & 1.2 & 0.42 \\
\hline \multicolumn{5}{|c|}{ Total power } & 8.88 & 6.92 \\
\hline
\end{tabular}

The table consists of Total Firm Capacity (MW) and MAX Demand (MW)

The max power demand recorded at summer time around 7.1 MW so the power plant and the transmission line calculation based on the max figure of power demand recorded. although the figure above of fuel consumption compare to oil production not representing latrge persantage but still it considered as high cost and energy loss compare to the flared 
associated natural gas at the field without make any benefit from this losses of burned gases to atmosphere

\section{BLOCK 4 NATURAL GAS AVAILABILITY}

Petroleum resources are the estimated quantities of hydrocarbons naturally occurring on or within the Earth's crust. Resource assessments estimate total quantities in known and yet to-be discovered accumulations; resources evaluations are focused on those quantities that can potentially be recovered and marketed by commercial projects. [6]

A petroleum resources management system provides a consistent approach to estimating petroleum quantities, evaluating development projects, and presenting results within a comprehensive classification framework.

The estimation of petroleum resource quantities involves the interpretation of volumes and values that have an inherent degree of uncertainty. These quantities are associated with development projects at various stages of design and implementation. Use of a consistent classification system enhances comparisons between projects, groups of projects, and total company portfolios according to forecast production profiles and recoveries. Such a system must consider both technical and commercial factors that impact the project's economic feasibility, its productive life, and its related cash flows.

Petroleum is defined as a naturally occurring mixture consisting of hydrocarbons in the gaseous, liquid, or solid phase. Petroleum may also contain non-hydrocarbons, common examples of which are carbon dioxide, nitrogen, hydrogen sulfide and sulfur. In rare cases, non-hydrocarbon content could be greater than $50 \%$. The term "resources" as used herein is intended to encompass all quantities of petroleum naturally occurring on or within the Earth's crust, discovered and undiscovered (recoverable and unrecoverable), plus those quantities already produced. Further, it includes all types of petroleum whether currently considered "conventional" or "unconventional." Figure 4-1 is a graphical representation of the SPE/WPC/AAPG/SPEE resources classification system. [6]

The system defines the major recoverable resources classes:

- Production.

- Reserves.

- Contingent Resources.

- Prospective Resources,

- Unrecoverable petroleum

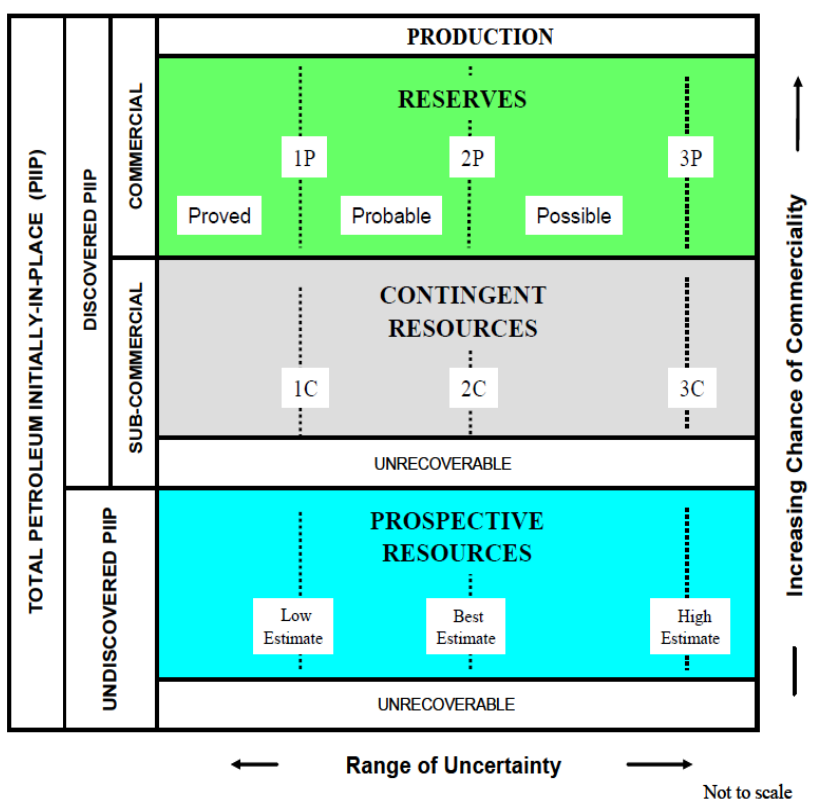

Figure (2) Resources Classification Framework [6] 1P:- min value of gas in place 2P: Most likely value of gas place 3P: min value of gas place B: billion GIIP:-Gas initial in place $\mathrm{R} F=$ Recovery factor $\mathrm{PR}($ potential recovery) $=2 \mathrm{P}$ GIIP $* \mathrm{RF}(\%)$

IV.Associated Gas Resource Availability Evaluation

The second major source of gas is the dissolved gas in oil. In Block 4, oil fields are categorized as:

- $\quad$ Producing Fields (PF)

- $\quad$ Tested Discovered Fields (TDF)

- Untested Discovered Fields (UTDF)

- Under Development Fields (UDF).

As of 2 B OPCO expected value (EV) for the Gas initial in place (GIIP), the producing fields represent 97 of the associated gas resources. Consequently, the following work focus on these fields. Nevertheless, associated gas resources from TDF are also evaluated here below.

The evaluation of the associated gas resources consists in:

- Checking the quality of seismic interpretation and depth maps

- Reviewing reservoir fluids PVT properties and initial contacts

- Calculating the oil and gas in place

Estimating Ultimate Recovery factors and remaining gas resources

According to the data available and the importance in term of Gas initial in place (GIIP) volume of the fields, the structural review focused on the following fields:

- Greater Neem Fields: Neem main and Neem K Fields

- Greater Diffra Fields: Diffra West and Hamam Fields

The structural review consisted in the following activities:

- Data collecting 
- Horizon and fault interpretation review

- Time to depth conversion review

- Depth maps validation.

The flowing table describe all gases Hydro carbon or other gases available in block 4:-

Table 3 Total Gas Hydro carbon or other gas

\begin{tabular}{|c|c|c|c|c|c|c|}
\hline \multirow[t]{2}{*}{ BLK } & \multirow{2}{*}{$\begin{array}{l}\text { 2P } \\
\text { GIIP } \\
\text { (BSCF) }\end{array}$} & \multirow[t]{2}{*}{$\begin{array}{l}\mathbf{R F} \\
(\%)\end{array}$} & \multirow{2}{*}{$\begin{array}{l}\text { PR } \\
\text { (BSCF) } \\
2 P\end{array}$} & \multicolumn{2}{|c|}{ Production } & \multirow{2}{*}{$\begin{array}{l}\text { REMAI } \\
\text { NING } \\
\text { PR (2P) }\end{array}$} \\
\hline & & & & Yea & Cum & \\
\hline 4 & & 44 & & 7.2 & & 238.9 \\
\hline Tot: & 765.1 & 44.4 & 339.9 & 7.3 & 101 & 238.9 \\
\hline
\end{tabular}

Most likely value of gas place by billion squire cubic feet are 765.1 with recovery factor of $44.4 \%$ so the potential recovery given by below equation :-

PR $(\mathrm{BSCF})=2 \mathrm{P}$ GIIP X RF $(\%)$

\section{$=765.1 \times$ 44.4= 339.9 BSCF}

The all gas available in block 4 is divided in to two parts of gases as per following tables:-

Table 4 Total Hydro carbon (HC) Gases [6]

\begin{tabular}{|c|c|c|c|c|c|c|}
\hline \multirow[t]{2}{*}{ BLOCK } & \multirow{2}{*}{$\begin{array}{l}2 P \\
\text { GII } \\
\text { P } \\
\text { (BS } \\
\text { CF) }\end{array}$} & \multirow{2}{*}{$\begin{array}{l}\mathbf{R F} \\
(\%)\end{array}$} & & \multicolumn{2}{|c|}{ Production } & \multirow{2}{*}{$\begin{array}{l}\text { REM } \\
\text { AINI } \\
\text { NG } \\
\text { PR } \\
(2 \mathrm{P})\end{array}$} \\
\hline & & & $2 P$ & $\begin{array}{l}\text { Yearl } \\
\mathbf{y}\end{array}$ & $\begin{array}{l}\mathrm{Cu} \\
\mathbf{m}\end{array}$ & \\
\hline Total & $\begin{array}{l}486 . \\
4\end{array}$ & 38.2 & 185.8 & 7.1 & 96.3 & 89.5 \\
\hline
\end{tabular}

Table 5 Total CO2 Gases [6]

\begin{tabular}{|c|c|c|c|c|c|c|}
\hline \multicolumn{7}{|c|}{ Total CO2 Gas } \\
\cline { 1 - 5 } BLO & 2P & RF & PR & Production & REMAI \\
CK4 & $\begin{array}{c}\text { GIIP } \\
\text { (BSC } \\
\end{array}$ & F) & & $\begin{array}{c}\text { NING } \\
\text { (BSCF }\end{array}$ & & PR (2P) \\
\cline { 4 - 6 } & & $2 \mathrm{P}$ & $\begin{array}{c}\text { Year } \\
\text { ly }\end{array}$ & Cum & \\
\hline Total & 278.7 & 55.3 & 154.1 & 0.2 & 4.7 & 149.4 \\
\hline
\end{tabular}

Table 6 Canar and Diffra Neem amount of associated and non-associated Gas [6]

\begin{tabular}{||c||c|c||}
\hline \multirow{2}{*}{ Field } & Associated Gas & Non Associated Gas \\
\cline { 2 - 3 } & GIIP BSCF & GIIP BSCF \\
\hline \hline Neem & $\underline{\mathbf{3 1 3 . 4}}$ & $\underline{\mathbf{3 9 7}}$ \\
\hline \hline Diffra & 41.35 & 8.33 \\
\hline
\end{tabular}

\begin{tabular}{||c||c|c||}
\hline Canar & 4.23 & 0.00 \\
\hline \hline Total & 358.98 & 405.33 \\
\hline
\end{tabular}

Table 6 chart Canar and Diffra Neem amount of associated and non-associated Gas ,Neem field in general is the main gas resource and available amount of natural gas which grantee continuous gas supply so it is recommended place for Gas utilization projects in block 4 is the main concern of this research, which study's possibility of generation of electrical power to meet the power consumption demand. [6]

\section{UTLIZING ASSOCIATED GAS IN TO ELECTRICAL POWER}

The process for converting the energy in a fuel into electric power involves the creation of mechanical work, which is then transformed into electric power by a generator. Depending on the fuel type and thermodynamic process, the overall efficiency of this conversion can be as low as 30 percent. This means that two-thirds of the latent energy of the fuel ends up wasted. For example, steam electric power plants which utilize boilers to combust a fossil fuel average 33 percent efficiency. Simple cycle gas turbine (GTs) plants average just under 30 percent efficiency on natural gas, and around 25 percent on fuel oil. Much of this wasted energy ends up as thermal energy in the hot exhaust gases from the combustion process. [7]

The first and agreed choice of the type of power plant technology to be used as prime mover is internal Combustion engines because they are a well-known technology used in electrical power generator.

Gas engines that run on natural gas typically have a high thermal efficiency, these gas engines are usually mediumspeed engines for the following features encourage the choice of gas internal combustion engine:-

Increased power range achieved by basing the design of largest engine platform done by engine manufacturer

Higher efficiency by lower gas consumption for the power produced and therefore lowers operating costs.

Reduced emissions Achieved through further developments of the well-known combustion system based on spark ignition

Increased availability the larger and slower-running engine has an natural advantage over smaller faster-running engines. However, the high availability is primarily founded in a simple and robust engine design, which has been thoroughly tested and is built to the highest quality standards.

Reduced service cost per $\mathrm{kWh}$ This is due to the simple and robust design of the gas engine, with fewer parts subject to wear, Therefore the intervals between overhauls can be longer, giving a lower service cost per produced $\mathrm{kWh}$.

Wide fuel-gas specifications this remains a factor not to be overlooked, and in being an "Otto cycle" Lean Burn S.I. engine with a fully bore-cooled combustion space, gas has low anti-knocking requirements compared to alternative gas engine types. 


\section{OPTIONS OF PROPOSED SOLUTIONS}

When using the Gas engine there are two Options for proposed solutions are have been studied for this research of gas to power utilization in electrical power generation, proposed solutions options started from brain storming sessions have been conducted with concerned parties in the electrical power department, development department, Reservoir engineering, sub-service Department which come out to the following options with their scenarios:-

\section{Option (1): Placing individual units at Diffra and Neem} fields.

- Scenario A Gas Into crude oil Pipeline

- Scenario B New Gas Pipe line

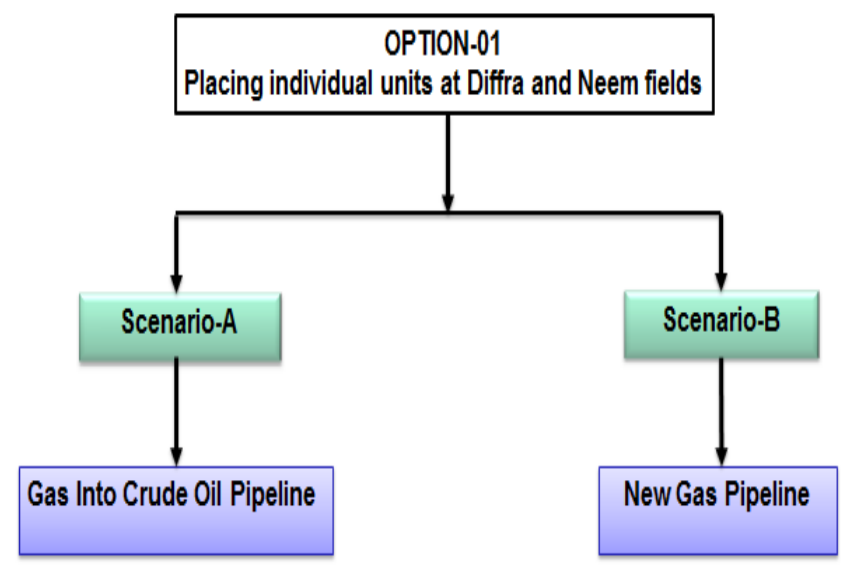

Figure (4) option 1 Placing individual units at Diffra and Neem fields

Option (2): Placing All Units at Neem and Construct OHTL linking Neem with Diffra and Canar

- Scenario A Rental Gas Engines

- Scenario B Purchase Gas Engines

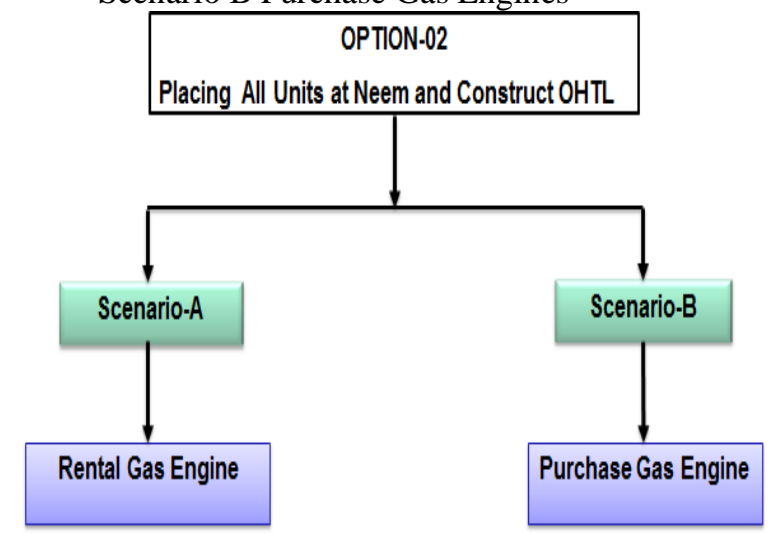

Figure (5) option 2 Placing All Units at Neem and Construct OHTL

Option 1 Placing individual units at Diffra and Neem.

1-Placing Individual Units at NEEM Field:

Place gas Engines to be installed at NEEM to cover the power requirements at the field and the fuel gas Source will be from NEEM FPF and the main reason for this option that (Neem Field) has the most reliable Gas availability and sustainability .

\section{2- Placing Individual Units at DIFFRA:}

Place same gas Engines to be installed at DIFFRA to cover the power requirements at the field but Due to High uncertainty of Gas availability in Diffra field, fuel gas Source needed to be transferred from NEEM to Diffra field this can be done through two scenarios:

Scenario-A Transfer Gas into Crude Oil Pipeline

Scenario-B Construct New Gas Pipeline to transfer

3-Transfer Gas into Crude Oil Pipeline (Scenario A)

Crude Oil from NEEM Field is transferring the to Diffra FPF for further processing through existing Diffra Heglig pipeline with following parameter's:-

Nominal pipe line size (NPS 16").

Design Pressure 77 barg

Design Temperature $85^{\circ} \mathrm{C}$

$100 \mathrm{Km}$ Pipe Length

Actual Pipeline operation Conditions:-

Flow Rate : 7200 Blpd

Water\%: $0.5 \%$.

Temperature: $65-70^{\circ} \mathrm{C}$

Crude Transferred to Diffra via Crude oil transfer pump (Centrifugal Type)

\section{Proposal Description:}

\section{(1) Gas Mount to MW}

The gas amount needed for the power generation calculated by manufacturer as per the following chart approximates the natural gas fuel consumption of an industrial or commercial generator based on the size of the generator and the load at which the generator is operating. Please note that this table is intended to be used as an estimate of how much fuel a generator uses during operation and is not an exact representation due to various factors that can increase or decrease the amount of fuel consumed.

Table (5) Natural gas fuel consumption

\begin{tabular}{|c|c|c|c|c|}
\hline Generator Size (kW) & $1 / 4$ Load ( $\left.\mathrm{ft}^{3} / \mathrm{hr}\right)$ & 1/2 Load ( $\left.\mathrm{ft}^{3} / \mathrm{hr}\right)$ & 3/4 Load (ft $\left.t^{5} / \mathrm{hr}\right)$ & Full Load (ft $\left.\mathrm{ft}^{\mathrm{s}} \mathrm{hr}\right)$ \\
\hline 20 & 157 & 188 & 247 & 289 \\
\hline 30 & 202 & 260 & 348 & 416 \\
\hline 40 & 246 & 333 & 449 & 543 \\
\hline 60 & 334 & 479 & 652 & 798 \\
\hline 75 & 400 & 588 & 803 & 990 \\
\hline 100 & 510 & 771 & 1056 & 1308 \\
\hline 125 & 621 & 953 & 1308 & 1627 \\
\hline 135 & 665 & 1026 & 1409 & 1754 \\
\hline 150 & 731 & 1135 & 1561 & 1946 \\
\hline 175 & 841 & 1317 & 1813 & 2264 \\
\hline 200 & 952 & 1500 & 2066 & 2583 \\
\hline 230 & 1084 & 1718 & 2369 & 2965 \\
\hline 250 & 1172 & 1864 & 2571 & 3220 \\
\hline 300 & 1393 & 2229 & 3076 & 3857 \\
\hline 350 & 1614 & 2593 & 3581 & 4495 \\
\hline 400 & 1834 & 2958 & 4086 & 5132 \\
\hline 500 & 2276 & 3687 & 5096 & 6407 \\
\hline 600 & 2717 & 4416 & 6107 & 7681 \\
\hline 750 & 3379 & 5509 & 7622 & 9593 \\
\hline 1000 & 4482 & 7332 & 10147 & 12780 \\
\hline
\end{tabular}


*Fuel consumption is based on 1015 Btu/standard ft3

\section{natural gas [8]}

From the table 5-1 above when consider the $1000 \mathrm{KW}$ (1 MW) gen set the amount of natural gas needed at full load is $12780 \mathrm{Ft}^{3} / \mathrm{hr}$ from Table (2) MAX firm power for Block4 power plant chapter (3) the max existing firm power is 8.88 $\mathrm{MW}$, the amount of gas needed to produces $8.88 \mathrm{MW}$ power will be as following:-

Max Natural Gas amount needed for existing firm power = $12780 * 8.88 * 24=\mathbf{2 7 2 3 6 7 3 . 6} \mathrm{Ft}^{\mathbf{3}}=\underline{\mathbf{2 . 7}} \mathbf{\text { mmscf }}$

The figure above of the max estimated amount natural gas of considered as being the input for the simulation program (Olga V 1.12108 Software simulation program) when this Amount of Gas injected (2.7 MMSCFD) in to main export Pipeline to be mixed with exported crude from Neem to Diffra FPF for further processing.
From the figure 6 below describe the additional process units required for this proposed solution and to be use in the simulation program (Olga V 1.1 2108 Software) so as to get the result of simulation.

Recommended Booster Compressor Specifications for the simulation Purpuse

Capacity: 3 MMSCFD.

Suction Pressure : 2-5 barg

Discharge Pressure : 12 barg

Discharge Temperature : $55^{\circ}$

Type: Screw Compressor.

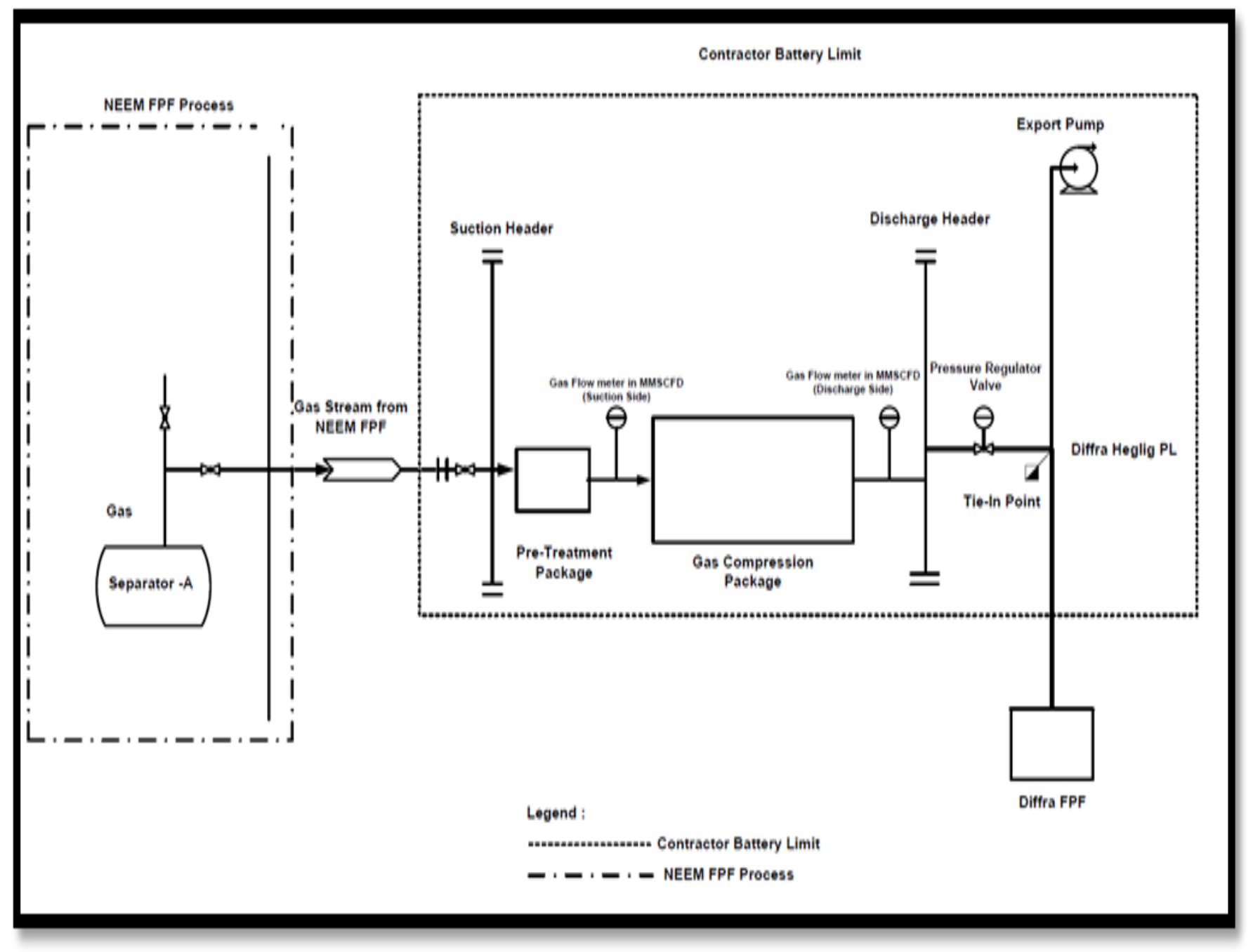

Figure (6) Crude Transferred to Diffra via Crude oil transfer pump

(A) Simulation SCENARIO A:-

The simulation inputs will consider the operation parameters for the process and the result outputs uses to compare operation conditions before and after gas injection. The parameters for simulation result will show the following :-

- Pipeline Elevation Profile

- The pressure profile of export pipe line.

- Temperature profile 
- $\quad$ Flow regime

(1) Simulation of Pipe line Elevation Profile:-

Elevation difference around 90 meters along the $100 \mathrm{~km}$ distance between Neem and Difffra field this considered because it will affect pressure drop calculations and flow regime (flow type) it will create and result in to slug flow profile..[9]

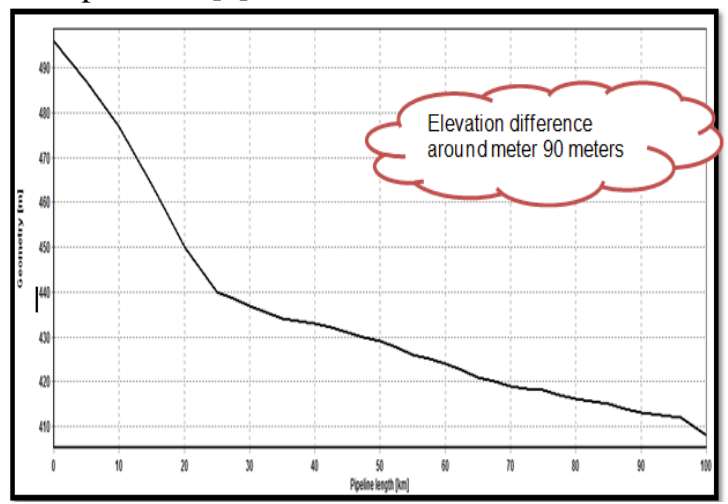

Figure (7) Pipeline Elevation Profile for actual operation condition[16]

(2) Simulation of Pipe line pressure profile:-

From the figure 8 Pipeline Pressure Profile for actual operation condition the pressure from Neem field lower as less than 2 bar and due to the elevation the pressure in the pipe line reached around 10 Bar at Diffra field, this pressure increment at Diffra FPF will affect positively in the process

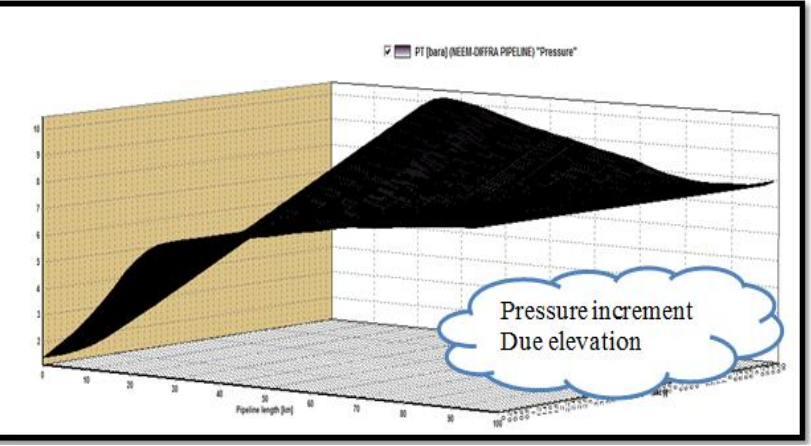

Figure (8) Pipeline Pressure Profile for actual operation condition [16]

(3) Simulation of Pipe line flow (regime) profile:-

Flow regimes are associated with different boundary conditions there are many types of flow regimes are usually identified, flow regimes are commonly encountered in horizontal oil and gas pipelines the software gives numbers to each flow type:

1-Stratified flow: Segregation of the gas and liquid phases, usually at low gas and liquid flow rates

2-Annular flow: The bulk liquid phase is partly atomized at high gas flow rate, leading to transport and deposition of droplets to the whole circumference of the pipe. 3-slug flow: the flow regime is not uniform in the pipe. Gas phase moves in separate pockets which are separated by columns (slugs) of the liquid phase.

4- Bubble flow: The gas phase is distributed in the liquid phase as variable-size, deformable bubbles moving upward with zigzag motions. The wall of the pipe is always contacted by the liquid phase

Figure 5-5 below shows the simulation result that the flow regime is Stratified flow type for the normal operation condition inputs so without gas injection [10]

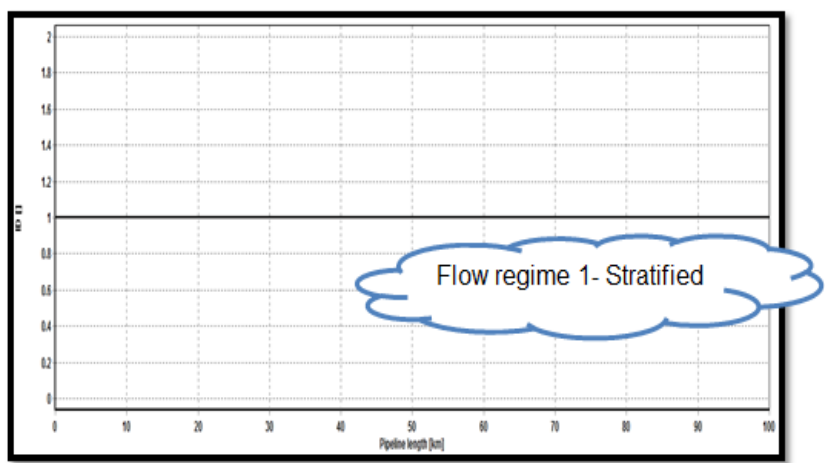

Figure (9) Pipeline flow regime (Profile) for actual operation condition [16]

Pipe line the flow regime will keep as stratified flow during normal operation period and this actually noticed. (4) Simulation of Pipe line temperature profile:-

The pipeline Temperature of crude oil flowing in a pipe gradually the temperature decreases along the line. If, however, the oil viscosity goes low and the inflow temperature move to close to the soil temperature, this visually seen in Figure (10) Pipeline temperature Profile for actual operation condition started from Neem filed at $70 \mathrm{Co}$ and goes down gradually to $24 \mathrm{Co}$ at 40th Kilometer.

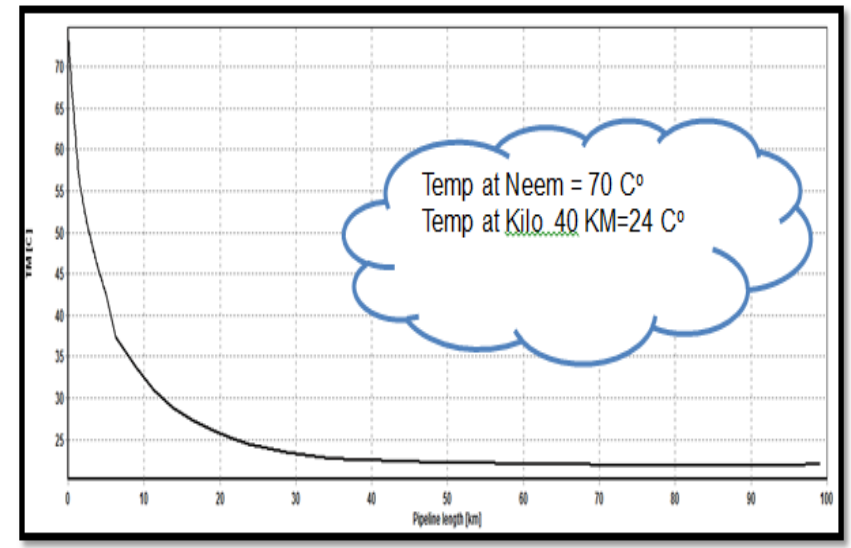

Figure (10) Pipeline temperature Profile for actual operation condition [16]

(B) Simulation RESULTS- The effect of injected gas SCENARIO A:-

The effect of injected gas has been studied for the following:

- Neem Defra Pipeline Flow Assurance. 
- Neem Defra Pipeline Integrity

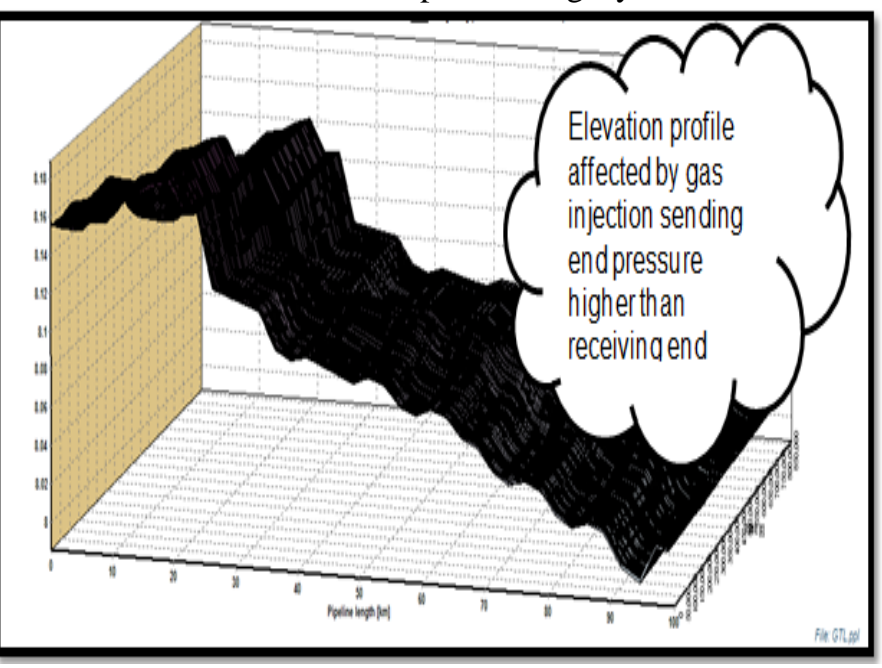

Figure (11) Pipeline Elevation Profile after gas injection [16]

Increment of the pipe line pressure at the Neem field sending end pressure higher than received end pressure at Defra field it is complete reversed profile before gas injected.

Simulation result of Pipe line flow (regime) profile:-

Flow regime as per the result of simulation OLGA program gives number 3 in the scale which is Slug type this phenomena start to happen near Defra filed @ around 70th Kilometer from Neem field, see Figure (12) Pipeline flow regime (Profile) for gas injection the internal metal surface of the pipe line at that place and with specific operation, temperature, pressure, fluid properties, and flow conditions, such as flow velocity and single- or multi-phase flows affect the pipe line and cause material removal by triggering corrosion process in oil and gas pipe line.

The existence of dissolved gases especially carbon dioxide in natural gas injected assists corrosion process to drastically reduce the pipe line thickness. Production pipe- lines involve the interaction between metal wall and the flowing fluids. Relative motion between the fluid and the metal surface win in general affect the rate of the corrosion.

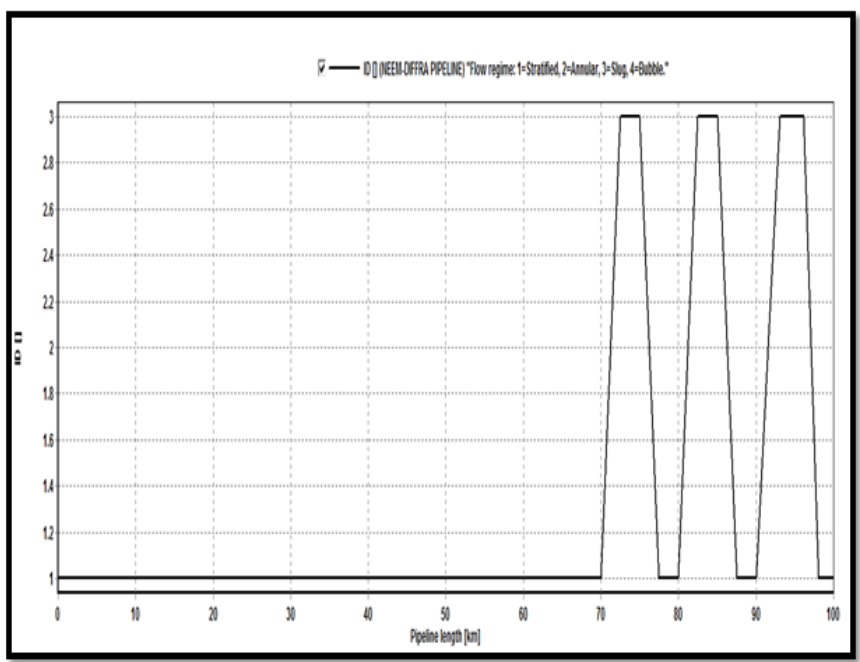

Figure (12) Pipeline flow regime (Profile) for gas injection [16]

\section{(D) Technical parameters of NEEM DIFFRA Pipe} Line:-

The following table shows the pipe line parameters for existing pipe line all data show the design parameters and all this parameters used for the program simulation inputs.

Table 6 Pipe line parameter [17]

\begin{tabular}{|l|l|}
\hline Parameter & Crude Line \\
\hline Pipeline Diameter & NPS 16" \\
\hline $\begin{array}{l}\text { Line Length (From Neem FPF To } \\
\text { Defra FPF) }\end{array}$ & $100 \mathrm{~km}$ \\
\hline Design pressure & $77 \mathrm{barg}(60 \mathrm{brag})$ \\
\hline Design Temperature & $85^{\circ} \mathrm{C}$ \\
\hline Corrosion allowance & $3.0 \mathrm{~mm}$ \\
\hline Pipe Material & API Spec.5L Gr.X56 \\
\hline Wall thickness & $9.5 \mathrm{~mm}$ \\
\hline $\begin{array}{l}\text { Pipeline burial depth to the top of } \\
\text { pipeline }\end{array}$ & $1.2 \mathrm{~m}$ \\
\hline Coating Conductivity & $0.22 \mathrm{~W} / \mathrm{m} . \mathrm{k}$ \\
\hline Coating thickness & $3 \mathrm{~mm}$ \\
\hline Ground Conductivity & $1.3 \mathrm{~W} / \mathrm{m} . \mathrm{k}$ \\
\hline Pipe Thermal Conductivity & $50 \mathrm{~W} / \mathrm{m} . \mathrm{K}$ \\
\hline Pipe Roughness & $\mathbf{5 . 1}$ \\
\hline
\end{tabular}

The table below shows the natural gas contents volume percentage showing different components

Table 7 Gas Composition[18]

\begin{tabular}{|c|c|}
\hline Component & Result (Vol \%) \\
\hline Nitrogen & 0.7 \\
\hline CO-2 & 0.96 \\
\hline Methane & 82.42 \\
\hline Ethane & 9.17 \\
\hline
\end{tabular}




\begin{tabular}{|c|c|}
\hline Propane & 4.39 \\
\hline I-Butane & 0.51 \\
\hline N-Butane & 1.11 \\
\hline Cis-Butane & 0.01 \\
\hline Iso-Butane & 0.23 \\
\hline N-Pentane & 0.27 \\
\hline More than C5 & 0.23 \\
\hline
\end{tabular}

\section{Conclution}

The pipeline operating parameters are within the pipeline design limit.

As per the above composition, the injected gas is not corrosive due to the low $\mathrm{CO} 2$ percent in the total gas composition, however, the $\mathrm{CO} 2$ need to be detected frequently in order to assure pipeline healthiness.

As a result of adequacy check, the amount of Slug Volume because of gas injection will be accommodated within Diffra Process Equipment (No need for new slug catcher) by diverting Neem Crude through Diffra Train$\mathrm{C}$ and to process Diffra and Canar Crude through Train A\&B See Figure (5-9) DIFFRA process Utilize Train -C to process the and separate the gas with minor modification it is just piping work adding some isolating valves and adding pipes to divert the gas flow in the process as shown in the figure(5-9) below [9]

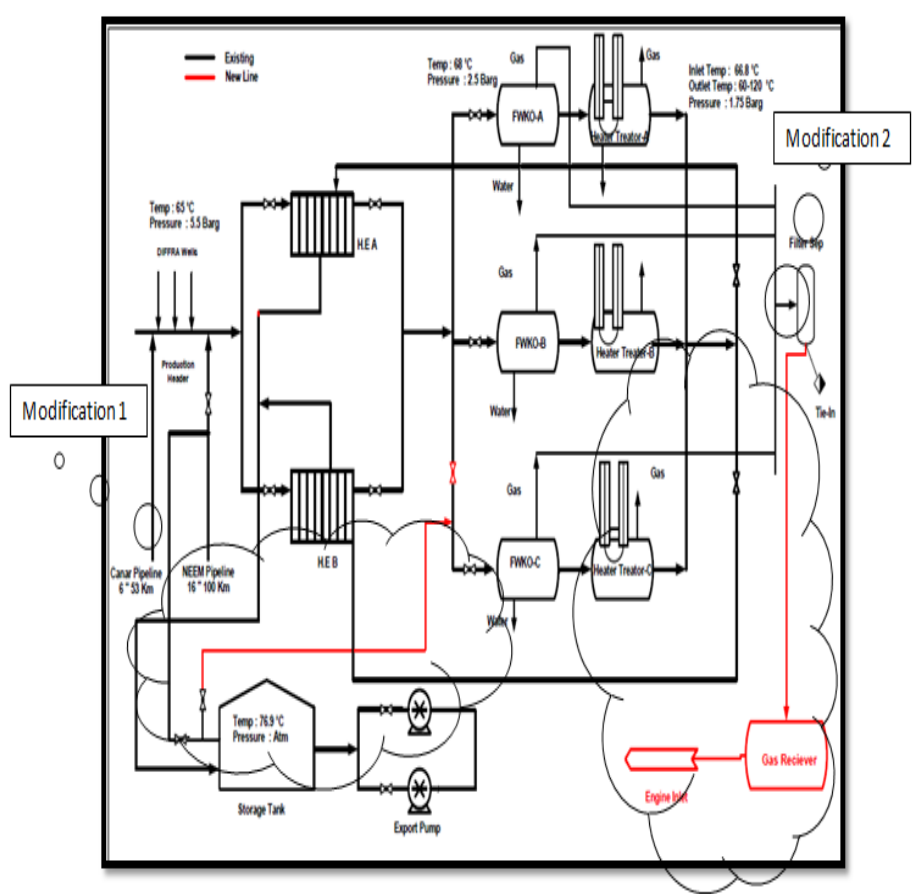

Figure (13) DIFFRA process Utilize Train $-\mathrm{C}$ to process the \&separate the gas

\section{COST ESTIMATION}

Table blew shows the Description of cost of the main project units extracted from the last contracts unit rate cost existing with contract department and usually used for such purpose.
Table 8 Cost estimation

\begin{tabular}{|l|l|l|}
\hline Item & Description & Cost \$ \\
\hline & Option-01 : & \\
\hline 1.0 & Procurement Cost : & 1000,000 \\
\hline 1.1 & $\begin{array}{l}\text { Gas Compression Package (Two } \\
\text { Units) }\end{array}$ & 5000 \\
\hline 1.2 & Pressure Regulator Valve & 10,000 \\
\hline 1.3 & Piping \& Fittings & 250,000 \\
\hline 1.4 & Gas Receiver (at Engine Inlet) & $1,265,000$ \\
\hline Total Procurement Cost & 170,000 \\
\hline 2.0 & Construction Cost : & 150,000 \\
\hline 2.1 & Tie-in Cost & $1,902,000$ \\
\hline 2.2 & Diffra FPF Modification & $2,900,000$ \\
\hline $\begin{array}{l}\text { Total Procurement \& Construction Cost with } \\
20 \% \text { Contingency }\end{array}$ & $\begin{array}{l}\text { EPCC project for construction of } 6 \\
\text { gas engines. }\end{array}$ \\
\hline 3.0 & Total Project Cost & \\
\hline 4.0 &
\end{tabular}

SCENARIO-B (New Gas Pipeline)

\section{Proposal Description:}

To construct new gas Pipe line from Neem FPF up to Diffra FPF to be utilized as a fuel for power generation units at Diffra Field and also to serve another purpose of gas utilization which is gas injection in future when come to project of reservoir enhancement.

The simulation module has been built to assess the main design parameters and to check acceptance criteria

\section{Simulation for SCENARIO-B}

The simulation module built to assess the main design parameters mainly three parameter as following

- Pressure

- Temperature

- Gas Velocity

Simulation Outcomes will be the recommended pipe size and then to assess the design specifications and discuss the effect of the operation condition on the pipe line robustness

(1) Simulation of pressure profile:-

Shown in Figure (9-10) pressure profile in case of new pipeline construction there are essential needs to consider not only the velocity but also the pressure drop in the pipeline.

As per above graph the system required pressure to deliver the gas from NEEM Filed to DIFFRA field are 27 barg to achieve 5 barg at diffra.the pressure dropped gradually as shown in figure 5-10 this is obviously noticed for the long distance gas (natural gas) transmission pipelines and the required pressure at the 
terminal end of the pipeline governs the line size along with the velocity.

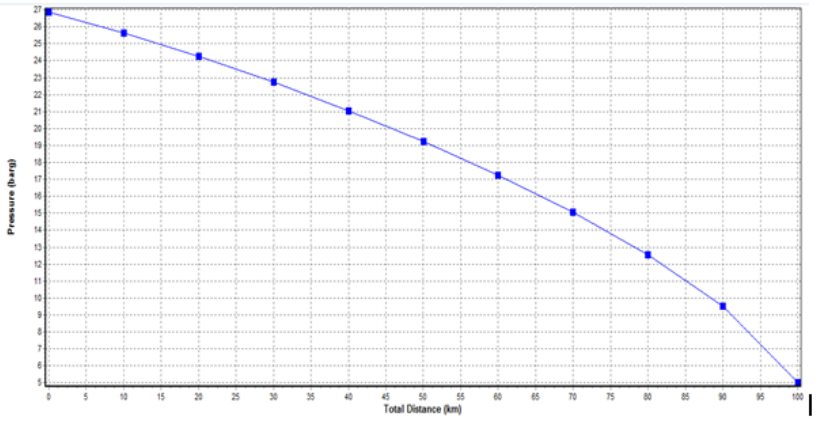

Figure (14) pressure profile for new gas pipe line[16]

\section{(2) Simulation of gas velocity:-}

There are considerations related to erosion due to high velocities which need to be taken into account. In case of new pipe line construction it is recommend that gas velocities in transportation of natural gas through longdistance pipelines should be in the range of low velocity in range of 5 to $10 \mathrm{~m} / \mathrm{s}$ for continuous operation and a maximum up to $20 \mathrm{~m} / \mathrm{s}$ for intermittent operation.

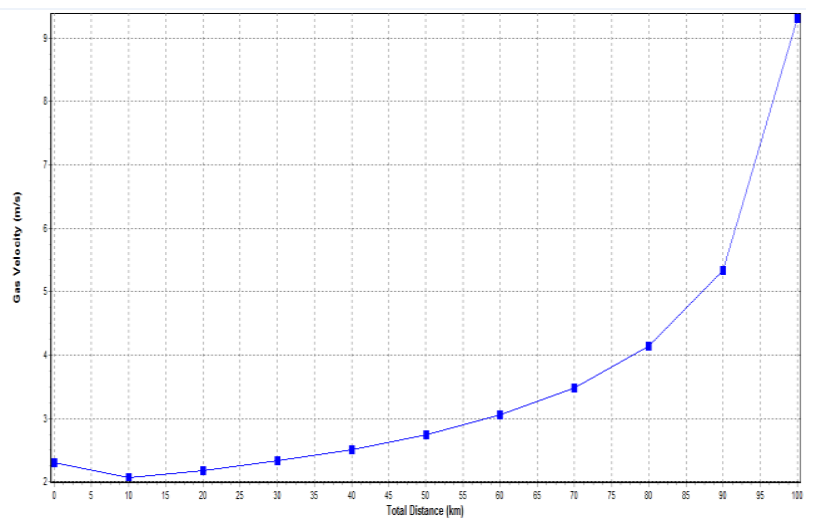

Figure 15 Normal operation gas velocity [16]

The normal sizing procedure for gas transmission pipelines is to assume a line size and check the pressure drop and velocity for the assumed line size using the OLGA software for single-phase gas pipeline, the software used to calculate the erosion velocity is shown in the graph the velocity increases gradually and reached $9.5 \mathrm{~m} / \mathrm{sec}$ at the receiving end.

To check if the velocity with in the safe range continuous operation so Figure 5-12 shows Erosional velocity profile to compare the result with the normal operation condition gas velocity.

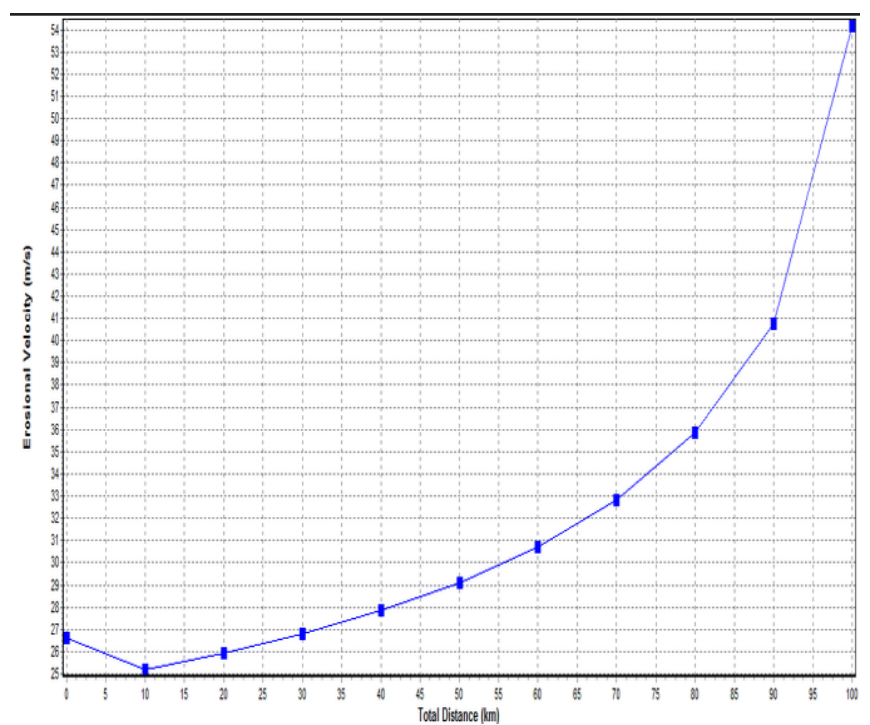

Figure 16 Erosional velocity[16]

The max erosional velocity around $\mathbf{5 4} \mathrm{m} / \mathrm{sec}$ and the normal velocity reach max around $9.5 \mathrm{~m} / \mathrm{sec}$ so the operational velocity less than the max range so the pipe line with the safe operation limit.

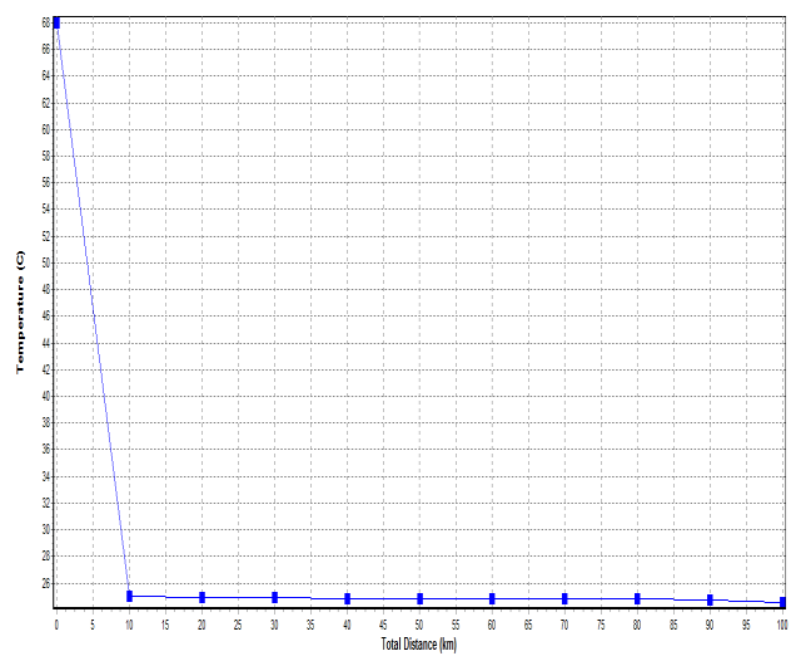

Figure 17 Temperature profile [16]

\section{Simulation of Temperature profile :-}

The gas temperature in pipeline would below the underground temperature of the burial depths. When the temperature drop to the lowest point, soil transfer heat to the pipe, so that the temperature of the ending pipe would decreases slowly. Fitting the relationship between temperature and distance are shown in Figure 5-13.

As shown in the last figure temperature rapidly drooped from $680 \mathrm{C}$ to $250 \mathrm{C}$ with the first 10 Kilometer of the pipe length then remains constant and equal to the ground temp due to no heat transfer.

This will not affect the transmission of the gas neither pipe line itself because of pretreatment package (dehydration package) will remove all gas condensate and moisture. 
From simulation program the Simulation Outcomes recommend the following:

- Pipe line Size $=6$ “

- General Arrangement: Buried pipeline.

- Buried Depth : $1.5 \mathrm{~m}$

All technical criteria for size selection have been met and considered (Temp, Pressure and Pressure drop with the safe operation limits).

\section{Option Requirement:}

Process gas will pass through new Booster compressor to compress the gas to the required pressure and then will be sent to DIFFRA through new gas pipeline.

Compressor should be equipped with dehydration package for pre-treatment purpose (Vendor to specify the type of dehydrator package).

Gas from Pipeline outlet will be sent to new power plant engines as a fuel for power generation.

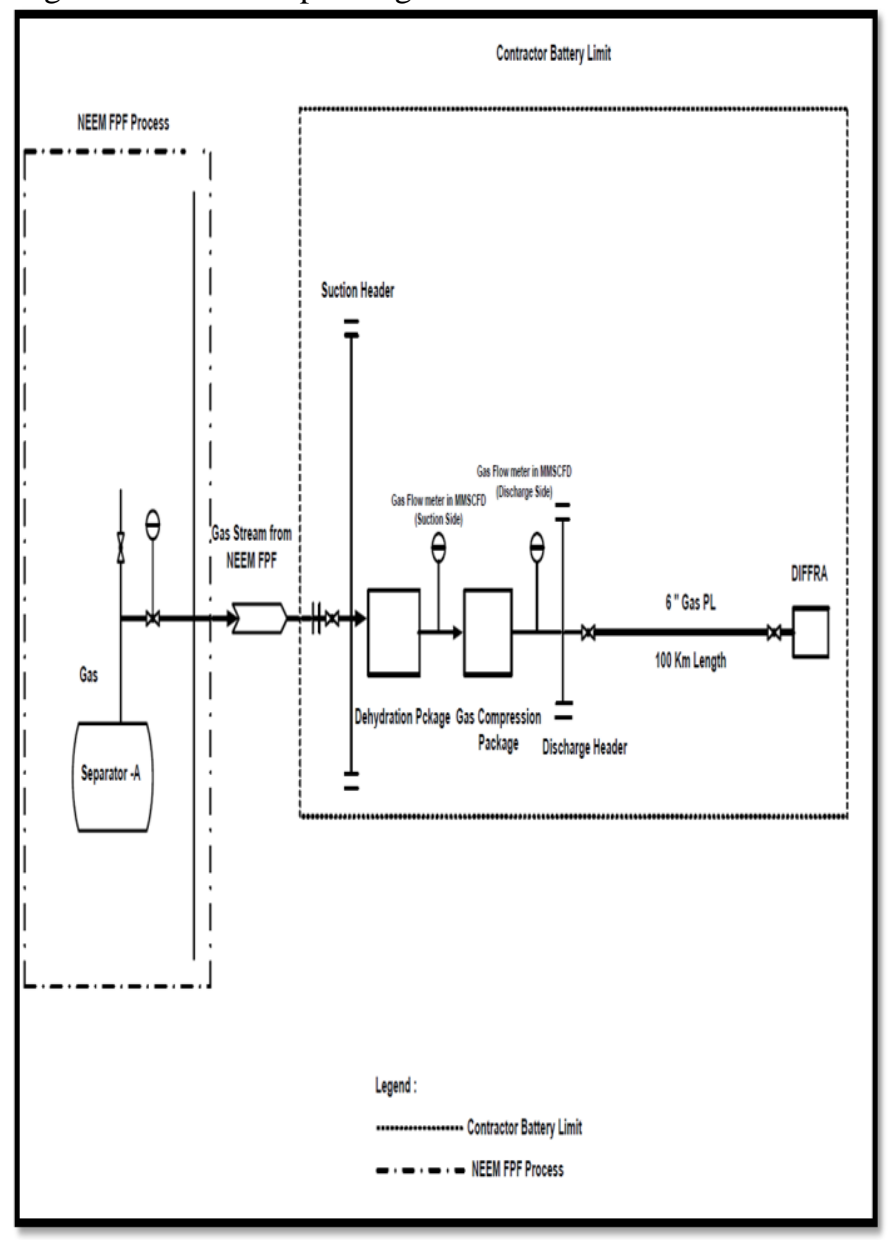

Figure (18) Process gas through Booster compressor

\section{Estimated Booster Compressor Specifications and} cost estimation

Compressor specifications construction for gas compression built according to recognized standards such as API 618/EN 1012-3.
The Compressor with speed control by a frequency converter and constructed for potentially explosive atmosphere according to the ATEX code directive.

The general following main specifications required for simulation purpose to give the nearest real results:-

- Capacity: Min 3 MMSCFD.

- Suction Pressure : 2-5 barg

- Suction Temperature : $40-65^{\circ} \mathrm{C}$

- Discharge Pressure : 10 barg

- Type: Screw Compressor.

Table blew shows the Description of cost of the main project units extracted from the last contracts unit rate cost existing with contract department and usually used for such purpose.

Table 8 Description of cost

\begin{tabular}{|l|l|l|}
\hline Item & Description & Cost \$ \\
\hline 1.0 & Procurement Cost & \\
\hline 1.1 & $\begin{array}{l}\text { Gas Compression Package.(Two } \\
\text { Units) }\end{array}$ & $1,200,000$ \\
\hline 1.2 & Piping \& Fittings. & $4,800,000$ \\
\hline Total Procurement Cost & $6,000,000$ \\
\hline 2.0 & Construction Cost : & $7,200,000$ \\
\hline 2.1 & New Pipeline construction & 471,461 \\
\hline 2.2 & $\begin{array}{l}\text { Construction of tie-in points } \\
\text { Total Construction Cost }\end{array}$ & $7,671,461$ \\
\hline 3.0 & $\begin{array}{l}\text { Total Procurement \& } \\
\text { Construction Cost with 20\% } \\
\text { Contingency. }\end{array}$ & $\begin{array}{l}16,405,753.2 \\
\text { Engineering Procurement } \\
\text { Construction and } \\
\text { Commissioning (EPCC) project } \\
\text { for construction of 6 gas } \\
\text { engines. }\end{array}$ \\
\hline \multicolumn{2}{|l|}{ Total Project Cost } & $\mathbf{2 4 , 3 0 5 , 5 7 3 . 2}$ \\
\hline
\end{tabular}

Conclusions for scenario A\& B Comparison

Table 9 Scenarios A\& B Comparison

\begin{tabular}{|c|c|c|}
\hline Scenarios & Advantages & disadvantages \\
\hline $\begin{array}{l}\text { Scenario-A } \\
\text { (Gas Into } \\
\text { Crude Oil } \\
\text { PL) }\end{array}$ & $\begin{array}{l}\text { - Low cost } \\
\text { compared to } \\
\text { the other } \\
\text { options. } \\
\text { - Some of } \\
\text { flared gas has } \\
\text { been utilized. } \\
\text { - Low } \\
\text { operation } \\
\text { Cost }\end{array}$ & $\begin{array}{l}\text { - Less Reliable option since } \\
\text { NEEM \& DIFFRA FPF } \\
\text { operation philosophy } \\
\text { needs to be modified to } \\
\text { meet the new conditions. } \\
\text { - Operation Interruption. } \\
\text { - Probability of increment } \\
\text { of corrosion rate because } \\
\text { of slug flow especially in } \\
\text { case CO2 amount. } \\
\text { - More close monitoring to } \\
\text { pipeline parameters. }\end{array}$ \\
\hline
\end{tabular}




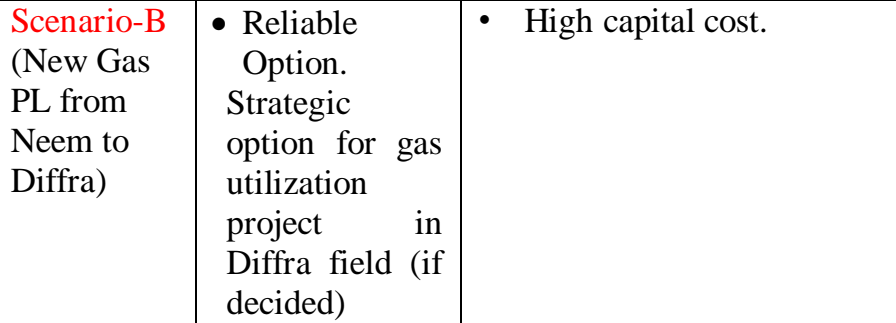

Option (2): Placing Power units at Neem and Construct

The recommended option as below with two scenarios for driven gas engines purchase or rental the engines as following:-

1- Gas driven Engines with $8 \mathrm{MW}$ installed power to cover BLK-04 power demand

2- Built Transmission line to supply power to other field.

Table 10 project CAPEX [10]

The following features required for the gas gensets needed for the continues power supplying to the field:-

- The required capacity to be installed is total of 8 MW

- Expected consumption to generate $8 \mathrm{MW}$ is 2.2 to 2.5 MMSCFD

- To sustain gas supply, storage capacity will be considered.

- The associated gas will require a limited pretreatment.

- The selection of suitable gas engine will be determined by direct market survey conducted by the Mechanical Engineering Department.

The following features of Overhead transmission line (OH/TL) :-

- Transmission Line from Neem to Diffra (approx. $102 \mathrm{KM})$

- Transmission Line (approx. $44 \mathrm{Km}$ ) length from Tee-off to CANAR

- The line route Diffra-Neem pipeline, thus require less construction, operation and security patrolling cost.

Table 11 Total estimated cost of transmission line

\begin{tabular}{|l|c|}
\hline ITEM & Cost MUSD \\
\hline $\begin{array}{l}\text { Cost of Neem Diffra (PCC) } \\
\text { Transmission Line (approx. 102 } \\
\text { KM) }\end{array}$ & $0.055 X 102=5.66$ \\
\hline $\begin{array}{l}\text { To construct Transmission Line } \\
\text { approx. 42 Km) }\end{array}$ & $0.055 \times 42=2.31$ \\
\hline$+30 \%$ contingency & $8 \times 0.3=2.3$ \\
\hline Total & $\mathbf{1 0 . 4} \underline{\text { MUSD }}$ \\
\hline
\end{tabular}

Scenario (A) Purchase Natural Gas Power Generation Plant

One of the conditions of proposed solution to consider the two Scenarios of Purchase and rental, this will be reflected to the economical modeling so as to give clear indicator to which option and scenario achieve the optimum solution technical and economically.

Purchase Natural Gas Gen sets and stop the Old or existing power plant to save the operation cost (fuel and Maintenance cost), with Full Engineering procurements, construction and commissioning (EPCC) Project of installing gens set units to produce $(8 \mathrm{MW})$ power from Nature Gas Engines.

Table 10 Estimated Capital expenditure (CAPEX) of the project[13]

Table 12 Total estimated cost reduction in operation expenditure (OPEX) of project [10]

\begin{tabular}{|l|c|c|c|}
\hline \multicolumn{4}{|c|}{ Estimated reduction in OPEX from the new set up } \\
\hline $\begin{array}{l}\text { Station Fuel } \\
\text { cost }\end{array}$ & $\begin{array}{l}\text { Current } \\
\text { OPEX } \\
\text { (MUSD/Y) }\end{array}$ & $\begin{array}{l}\text { New } \\
\text { setup } \\
\text { OPEX }\end{array}$ & $\begin{array}{l}\text { Expected } \\
\text { saving }\end{array}$ \\
\hline $\begin{array}{l}\text { DIFFRA PP } \\
\text { (Diesel) }\end{array}$ & $\mathbf{4 . 3 9}$ & $\underline{\mathbf{0 . 1 0}}$ & $\underline{\mathbf{4 . 2 9}}$ \\
$\begin{array}{l}\text { CANAR PP } \\
\text { (Diesel) }\end{array}$ & $\mathbf{1 . 0 4}$ & $\underline{\mathbf{0 . 0 2}}$ & $\underline{\mathbf{1 . 0 2}}$ \\
\hline $\begin{array}{l}\text { NEEM PP } \\
\text { (Crude) }\end{array}$ & $\mathbf{3 . 1 9}$ & $\underline{\mathbf{0 . 1 6}}$ & $\underline{\mathbf{3 . 0 3}}$ \\
\hline $\begin{array}{l}\text { O \& M cost } \\
\text { NPP }\end{array}$ & $\mathbf{0 . 8 3 5}$ & $\underline{\mathbf{0 . 6 2}}$ & $\underline{\mathbf{0 . 2 2}}$ \\
\hline Total & $\mathbf{9 . 4 6}$ & $\mathbf{0 . 9 0}$ & $\underline{\mathbf{8 . 5 6}}$ \\
\hline
\end{tabular}

Scenario (B) Rental of Natural Gas Power Generation Plant

The second scenario is rental scenario, from the survey the cost of power per day the average cost of 17000 USD/day for the required power ( $8 \mathrm{MW})$.

Table 13 Estimated OPEX from the new set up (Rental case) [10]

\begin{tabular}{|l|c|c|c|}
\hline $\begin{array}{l}\text { Station Fuel } \\
\text { cost }\end{array}$ & $\begin{array}{l}\text { Current } \\
\text { OPEX } \\
\text { (MMUSD } \\
\text { /Y) }\end{array}$ & $\begin{array}{l}\text { New setup OPEX } \\
\text { (MMUSD/Y) }\end{array}$ & $\begin{array}{l}\text { Expected } \\
\text { saving } \\
\text { (MMUS } \\
\text { D/Y) }\end{array}$ \\
\hline $\begin{array}{l}\text { Rental of } \\
\text { Natural Gas } \\
\begin{array}{l}\text { Gen set } \\
\text { Units }\end{array}\end{array}$ & 0 & $\begin{array}{l}\mathbf{1 7} \text { KUSD/day * } \\
\mathbf{3 6 5} \\
=\underline{6.3 \mathrm{MUSD} / Y}\end{array}$ & - \\
\hline DPP(Diesel) & 4.39 & $\underline{0.10}$ & - \\
\hline CPP(Diesel) & 1.04 & $\underline{0.02}$ & - \\
\hline NPP(Crude) & 3.19 & $\underline{0.16}$ & - \\
\hline $\begin{array}{l}\text { O \& M cost } \\
\text { NPP }\end{array}$ & 0.835 & $\underline{0 *}$ & - \\
\hline Total & $\mathbf{9 . 4 6}$ & $\mathbf{6 . 5 8}$ & $\mathbf{2 . 8 8}$ \\
\hline
\end{tabular}


*Operation and maintenance cost $(\mathrm{O} \& \mathrm{M})$ included in the rental fees

Table 14 Scenarios Summary of Recommended

Proposal

\begin{tabular}{|l|l|l|}
\hline Scenario/ option & $\begin{array}{l}\text { Capex } \\
\text { MUSD }\end{array}$ & $\begin{array}{l}\text { Expected saving Opex } \\
\text { MUSD }\end{array}$ \\
\hline$\underline{\text { Purchase }}$ & 16.2 & 8.56 \\
\hline$\underline{\text { Rental }}$ & 10.4 & 2.88 \\
\hline
\end{tabular}

\section{Economic Evaluation}

The economical modelling considering the following facts and conditions:-

- Power generation by using of available gas associated or non-associated gas without considered gas treatment.

- The Current gas amount available from all field sites is around 15-18 mmscfd gas is available where the consumption of the gas to generate around $8 \mathrm{MW}$ will not exceed 2.2 to 2.8 mmscfd.

- The High Operation expenditure (OPEX) in existing system due to the cost of Crude oil fuel and diesel fuel in additional to maintenance cost.

- Existing Power System capacity of $\max 8.88$ MW installed power.

- New Power Plant capacity of 8 MW with Gas units \& Demand of 7 MW.

- Existing power system can be used as standby...

- Environmental impact by reduction of gas flaring.

Economics model based on following Assumptions:

- Gas Power unit with two Scenarios of Purchase or Rental

- Construction of Transmission Line (TL) length around $144 \mathrm{~km}$ to connect the three oil fields together estimated cost form the market survey equal to $\$ 0.055 \mathrm{MM} / \mathrm{Km}$, cost of transmission line existing in the two scenarios.

- Expected gas consumption is about 2.2 - 2.8 mmscf per day with to produces min to max power required respectively.

- The economical modeling will cover the period from JUNE 2019 up to End Of 2030

- Discount rate is $12 \%$.

Net present value for the project considering the two scenarios:-

The net present value calculation is a popular method used by business managers to evaluate the profitability of different projects. It is easy to use but it also has certain limitations.

The benefit of the NPV method that it considered that dollars received in the future are worth less than dollars in the bank today and Stockholders can see clearly how much a project will contribute to their value.

But some problems appear when using the NPV is that it requires guessing about future cash flows and estimating a company cost of capital. [11]

$$
\begin{aligned}
\mathrm{NPV}=- & C_{0}+\frac{C_{1}}{1+r}+\frac{C_{2}}{(1+r)^{2}}+\frac{C_{3}}{(1+r)^{3}} \ldots \ldots+\frac{C_{T}}{(1+r)^{T}} \ldots \ldots \ldots . . . \ldots q u(5-2) \\
& \mathrm{C}_{0}=\text { Initial Cost } \\
& \mathrm{C}=\text { Cash flow } \\
\mathrm{r} & =\text { Discount Rate } \\
\mathrm{T} & =\text { Time }
\end{aligned}
$$

\section{Net present value for Purchase scenario}

To study this scenario there are some assumptions should be fulfilled:-

The project time 11.5 Year starting from June 2019 up to end of 2030.

Capital cost (Capex):16.2 MMUSD.

Total saving Amount: 8.56 MMUSD.

Total Operation Cost (Opex):10.93 MMUSD

Operation and maintenance cost from 2019 to 203 for the new setup of power system details as shown in table 5-12 below :-

Table 15 Operation and maintenance cost from 2019 to 2030[15]

Item $1 Y r \quad 2019$ 2020--- 2025-- 2030 Total

\begin{tabular}{|c|c|c|c|c|c|c|c|c|c|c|c|c|c|c|c|}
\hline PIRSHHSI & Years & 1 & 1 & $!$ & 3 & 4 & 5 & 6 & 1 & 8 & 9 & 10 & 11 & 12 & Iotal \\
\hline Intida cost & & 16.2 & & & & & & & & & & & & & \\
\hline Expensess & & & 053 & 19 & 105 & 005 & 005 & 005 & 095 & 005 & 005 & 095 & 005 & 005 & 1098 \\
\hline $\operatorname{income}(\operatorname{sxing})$ & & & 499 & 886 & 866 & 836 & 8.66 & 856 & 8.66 & 856 & 8.56 & 856 & 8.66 & 836 & 99.15 \\
\hline Aon:Discounted cash flort & & & 4.46 & 1.66 & 7.61 & 7.61 & 7.61 & 7.61 & 7.61 & 76. & 7.61 & 7.61 & 7.61 & 7.61 & 8822 \\
\hline Discouted casin Dor & & & 399 & 6.11 & 5.4 & 4.84 & 43. & 3.86 & 3.4 & $3.0^{\circ}$ & 274 & 2.5 & 219 & 195 & 4.37 \\
\hline IPV & & 28.17 & & & & & & & & & & & & & \\
\hline
\end{tabular}

O\&M Cost

$\begin{array}{llllll}(\$ M M) & 0.53 & 0.9--- & 0.95-- & 0.95 & \mathbf{1 0 . 9 3}\end{array}$

Table 16 Excel Sheet NPV calculation for Purchase scenario [12]

Discounted Cash flow Up to $=\underline{44.37}$ MMUSD

Net present Value NPV $=\underline{\mathbf{2 8 . 1 7} \text { MMUSD }}$

Net present value for Rental scenario:-

To study this scenario there are some assumptions should be fulfilled:-

- The project time 11.5 Year starting from June 2019 up to end of 2030.

- Capital cost (Capex):10.4 MMUSD.

- Total saving Amount 8.56 MMUSD.

- Total Operation Cost (Opex):10.93 MMUSD

Table 17 Excel Sheet NPV calculation for Rental scenario [12] 


\begin{tabular}{|c|c|c|c|c|c|c|c|c|c|c|c|c|c|c|c|}
\hline REVTAL & lears & 1 & 1 & $!$ & 1 & 4 & $i$ & 6 & 1 & 8 & 9 & 110 & 11 & & Itol \\
\hline atidat ant & & 104 & & & & & & & & & & & & & \\
\hline Exposane & & & 3.68 & 63 & 63 & 6.3 & 6.3 & 63 & 6.3 & 63 & 63 & 6.3 & 6.3 & $6.3^{\circ}$ & 7268 \\
\hline $\operatorname{lnome}(x \operatorname{sing})$ & & & 499 & 8.6 & 8.66 & 8.66 & 8.66 & 836 & 8.56 & 8.66 & 8.66 & 8.66 & 8.56 & 8.66 & 90,15 \\
\hline 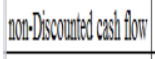 & & & 132 & 2.66 & 2.66 & 226 & 2166 & 226 & 2.66 & 2.66 & 226 & 2.66 & 2.26 & 2.66 & 26.18 \\
\hline Disountad Aor asid & & & 1.18 & 1.80 & 1.61 & 1.4 & 1.28 & 1.14 & 1.02 & 0.91 & 0.81 & 0.73 & 0.65 & & 13.16 \\
\hline I.PT & & 2.76 & & & & & & & & & & & & & \\
\hline
\end{tabular}

Discounted Cash flow $=13.86$ MMUSD

Net present Value NPV $=3.46$ MMUSD

Summary:-

For the purchase scenario as shown in table 5-13 the discounted cash flow 44.37 MUSD and the Net present Value NPV 28.17 MUSD.

For the Rental scenario as shown in table 5-14 the discounted cash flow 13.86 MUSD and the Net present Value NPV 3.46 MUSD.

Purchase option is better than Rental option from discounted cash flow and NPV point of view.

\section{CONCLUSION}

The implementation of the new technology of using gen sets to utilize natural gas in power generation will significantly decrease the fuel consumption diesel or crude oil which will decrease the overall operation and maintenance cost.

Construct and Use new transmission line connected the block 4 oil fields at the low cost like what the company usually used in the normal distribution electrical power network system in the field that resulted in decreasing the amount of losses and cost of maintenance, patrolling and fault finding time this amended design of the OH/TL will significantly reduce the project overall cost.

The implementation cost of the project with it is two parts (Purchasing \&Constriction of $\mathrm{OH} / \mathrm{TL}$ ) will be around 16.2 MUSD compared to the total saving achieved during next 11.5 years which will give discounted Cash flow around 44.37 MUSD with net present value NPV 28.17 MUSD with purchase the gas engine scenario.

The visible achievement is utilize part of associated gas in power generation to reduce /stop the High fuel consumption (crude/Diesel) with other associated logistic issues (Security issues, flooded area in rainy seasons cutting the rods, difficulty of earth movement). Utilizing the natural gas reduces the environmental impact of the existing power system generation because it has lower net carbon dioxide emissions in absence of carbon capture.

\section{RECOMMENDATION}

It's recommended to implement the technology the new technology of natural gas for power generation to block 4 fields to reduce the fuel consumption minimize the operation and maintenance cost.

Apply the same technology in all other similar industrial our utilities power supply system's after completing necessary studies shall reduce operational and maintenance cost.

Hazard operability (HAZOP) study should be carried out for Neem Power Plant in view of this addition.

The line engineering and construction will be suitable for $33 / 66 \mathrm{KV}$ with adequate provisions.

\section{ACKNOWLEDGMENT}

I would like to express my deep gratitude to Eng : Mazin Hassan yusif (Snionr Process Engineer Centroid Technical Services Co. ltd) for his effort on OLGA software to simulate the process and offer all required results also thak for Professor: Mohamed Ibrahim Sukri, (Nile Valley University) for his useful guidance,. I would also like to thank Dr. Hassan Khalifa (International University of Africa-IUA), my research supervisors for he is advice and assistance he is patient guidance, enthusiastic encouragement and useful critiques of this research work.

Finally, I wish to thank my parents for their support and encouragement throughout my study.

\section{REFERENCES}

[1] Subhojit Dawn،(EDs) Valentina Emilia (2019)"Intelligent Techniques and Applications in Science and applications in science and technology, $\mathrm{p}$, $132-156$

[2] Jones, D.A. (1991), "Electrical engineering: the backbone of society" P, 10-87

[3]iea.org/reports/the-oil-and-gas-industry-in-energytransitions, World Energy Outlook special report, Fuel report - January $2020 \mathrm{P}, 8-12$

[4] Block-4 Gas Power Generation, 2018- ... GNPOC, Dev Dept., project and facility team, Gas to power study report $\mathrm{p}, 5-8$

[5] E\&P Magazine, May (2017), accessed "Sudan \& South Sudan Power Report Q4 2017,” BMI Research, , p $13,17$.

[6] , Beicip-Franlab,(2.013) Third Party Inspection of Gas Reserves final report, $\mathrm{p}$ 16-187

[7] Lairize Baha DoriK , (2014 )Natural Gas Processing Technology and Engineering Design, 2nd Edition, p156, 157

[8]Consultancy, project No2111083, https://www.generatorsource.com/Natural_Gas_Fuel_Co nsumption.aspx 
[9] C. Lyons, Ph.D., P.E., Gary J. Plasa, B.S, Standard Handbook of Petroleum \& Natural Gas Engineering, Second Edition,p160-176

[10] Alireza Bahadori ,Processing, Technology and Engineering Design, Elsevier Science 2014,P59,150

[11] Ma J, Hsiao CT, Chained GL. Euler-lagrange simulation of bubble cloud dynamics near a wall. ASME J Fluids Eng. 2015 Apr; 137(4):041301-041311

[12] Khan, M.Y. (1993). Theory \& Problems in Financial Management. Boston: McGraw Hill Higher Education. ISBN 978-0-07-463683-1
[13] , Planning Section ,Economic Evaluation of New Gas Power Plant study 2B OPCO, final report P, 12-45 [14] 2 B OPCO financial department ,Economic Sensitivity Analysis Final Report, 2019, p 4.

[15] Management committee [MC paper], 2018

Gas Utilization for Power Generation in Blk 4

[16] Olga V 1.1, 2108 Software simulation program,Simlliation Results, management consultancy Dept process engineering section.final report. 